\title{
Level of Service Evaluations For Stormwater Performance Assessments
}

\author{
Michael A. Gregory, Michael F. Schmidt and John A. Aldrich
}

\begin{abstract}
A level of service (LOS) evaluation is a condition assessment to determine the stormwater system's level of performance with respect to site-specific numeric criteria. These LOS criteria can be used as benchmarks to gage the performance of existing systems and facilitate proper management decisions concerning the administration, operation, maintenance, and capitalization of stormwater assets. This chapter presents a brief background on general asset management for stormwater systems and some of the concepts and philosophies of establishing LOS standards/objectives. These concepts are exemplified by case studies highlighting various practical applications of LOS evaluations, including corroboration of observed system behavior, verification of model results, and an identification of existing system deficiencies and problem areas.
\end{abstract}

\subsection{Introduction}

Municipal infrastructure includes public utility systems for the collection, treatment, storage and distribution of potable water, wastewater, stormwater, and solid waste, as well as facilities for transportation and other public services. Infrastructure is capital intensive and represents a valuable public asset that plays a significant role in the quality of our lives and in the future development and growth of our communities (National Research Council, 1994). As a result,

Gregory, M., M.F. Schmidt and J. Aldrich. 2003. "Level of Service Evaluations For Stormwater Assessments." Journal of Water Management Modeling R215-04. doi: 10.14796/JWMM.R215-04. (C) CHI 2003 www.chijournal.org ISSN: 2292-6062 (Formerly in Practical Modeling of Urban Water Systems. ISBN: 0-9683681-7-4) 
the management, operation, maintenance, and capitalization of municipal infrastructure assets must be conducted in an efficient and cost-effective manner.

In addition to local government operation and maintenance concerns and development pressures, emphasis on improved infrastructure management is also being promoted through new political and regulatory forces. These include:

- A new policy of the Government Accounting Standards Board (GASB), GASB Statement 34, which requires state and local government units to report a more complete financial statement that better reflects the value of their infrastructure.

- The U.S. Environmental Protection Agency's National Pollutant Discharge Elimination System (NPDES) permit program, which includes requirements for the management and maintenance of stormwater systems.

- New rules recently issued by the US Environmental Protection Agency to address sanitary sewer overflows, known as Capacity Management Operations and Maintenance (CMOM). CMOM will require local governments to demonstrate that their sanitary sewer collection systems maximize and maintain the capacity of their sewer systems in order to eliminate overflows.

- Increased attention to the security of critical infrastructure systems as a result of the terrorism events of September 11, 2001. In the United States, a number of bills have been introduced into Congress to provide federal infrastructure improvement grants. To be eligible for this funding, local governments would be required to have asset management plans in place for their infrastructure systems.

Stormwater systems are especially in need of improved management and many local governments are treating stormwater facilities more like traditional public utilities, which feature involvement by multiple owners, stakeholders and practitioners and are influenced by many environmental, societal, or financial impacts. Rapid population growth and development pressures, deteriorating collection systems and facilities, persistent flooding and water quality concerns, as well as new state and federal mandates are increasing the complexity of managing stormwater. This complexity makes performance assessment necessary.

The purpose of this chapter is to highlight issues and approaches in the performance assessment of stormwater systems as part of improving their management. 


\subsection{Management of Stormwater Systems}

Like other municipal infrastructure, stormwater systems often cover large geographical areas and feature complex and dynamic components. These components include:

- conveyance channels and conduits (e.g. rivers, streams, canals, ditches, culverts, pipes, streets, swales);

- storage facilities (e.g. lakes, ponds, detention/retention facilities, and street/yard surface depressions); and

- special control structures (e.g. gates, orifices, weirs, pumps)

An important characteristic of stormwater systems relates to its function within the overall network. The primary stormwater system represents the major drainage network of trunk sewers and open channels, whereas the secondary stormwater system represents the minor or local drainage network (e.g. inlets, collector pipes, ditches, and swales).

System components interact, such that changes in one component affect the operation and performance in others. In addition, these components and systems provide many services to many users including:

- water quantity and flood control;

- water quality and erosion/sedimentation control;

- water supply and aquifer recharge;

- wetlands management; and

- public recreation and aesthetics.

A comprehensive, system-wide approach to stormwater management has many advantages over a component or piecemeal approach. In a comprehensive approach, managers can assess the entire system over a wide range of efficiency opportunities, from low-flow conditions on dry days to the highflow conditions during rare storm events when property and lives are threatened.

\subsection{Stormwater Level of Service}

Defining an acceptable level of service to be provided by the stormwater system is the foundation of a comprehensive stormwater management plan (Roesner and Matthews, 1990). Once the policy decisions have been confirmed, the watershed specific goals and performance criteria can be developed. The remainder of this chapter discusses how these goals and criteria can be used 
in the performance assessment of stormwater systems. The goals and criteria discussed in this chapter are limited to water quantity indicators; erosion, sedimentation, and water quality issues are not addressed.

The level of service (LOS) provided by a stormwater system is a measure of its function, ability, and/or capacity with respect to some set of performance criteria. LOS standards are intended to protect public safety by:

- assuring emergency access and evacuation route ingress and egress;

- limiting damage to public and private property; and

- minimizing other hazards due to stormwater flooding.

Developing watershed-specific LOS criteria involves translating local government drainage goals, objectives, and standards into a watershed context and then assigning measurable performance criteria. Broad objectives may include reducing or eliminating frequent flooding of residential, commercial, and industrial areas or transportation routes that create safety hazards, endanger property or disrupt the normal conduct of business. Specifically, a local government's LOS objective may be to provide safe passage of normal traffic flow during rainfall events, for example. For watershed planning purposes, these objectives could be interpreted into LOS criteria that stipulate a maximum depth of 3 inches $(75 \mathrm{~mm})$ of flooding over the road crown in all local and arterial traffic routes for the 5-y/24-h design storm event. Accordingly, stormwater LOS criteria define the degree and range of expected service to be provided by the system.

Level of service standards should allow for the variation in service expectations of those who benefit from the system. In rainy regions with flat topography, residents might be accustomed to relatively frequent occurrences of roadway and yard flooding. However, in steep areas or arid regions even nominal depths of flooding might not be tolerated, especially iffloodwaters have high velocities.

Furthermore, it is not uncommon for LOS criteria to vary between watersheds within the local government jurisdiction. One example of divergent opinions on service expectations is the distinction between nuisance flooding (e.g. incidental street or backyard flooding) and damaging flooding where there is a clear threat to life, property, or business operation. Figure 4.1 shows an example of minor nuisance flooding along a local road. Figure 4.2 shows an example of severe and damaging flooding along a major arterial route. In coastal communities, deeper and more frequent flooding of streets and yards might be expected in residential areas along the coast compared to what is considered acceptable in the downtown shopping district, for example. 


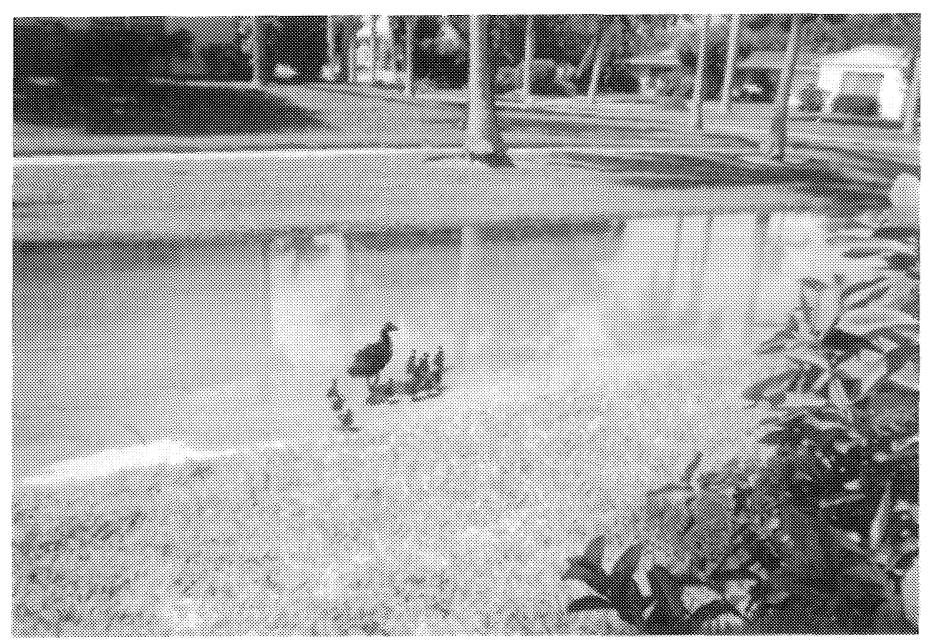

Figure 4.1 Minor nuisance flooding.

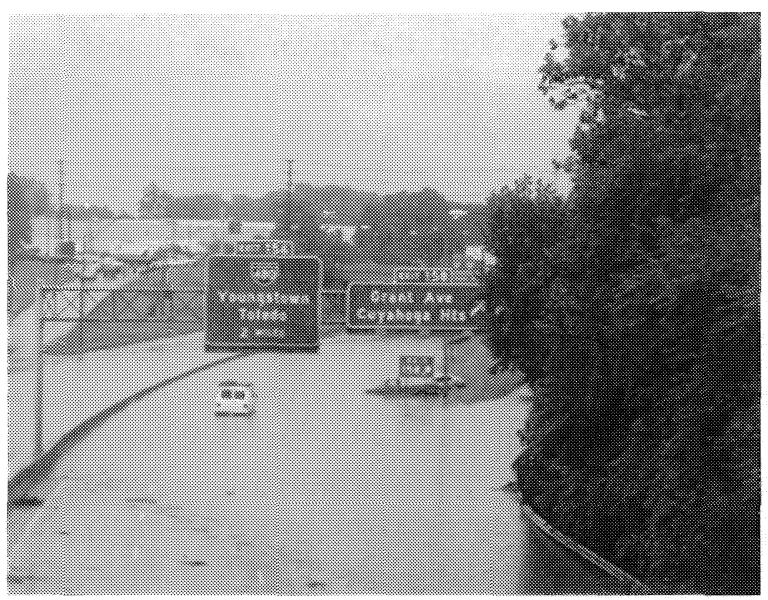

Figure 4.2 Severe flooding.

By applying LOS criteria throughout the watershed using hydraulic model results, a comprehensive, system-wide performance evaluation can be undertaken. This LOS evaluation can be used as a predictive tool to evaluate the system performance over a range of storm events, land use scenarios, or alternate LOS criteria. Specifically, an LOS evaluation can be used to: 
- corroborate observed system behavior;

- identify existing system deficiencies (i.e. locations where the LOS criteria are not achieved);

- prioritize problem areas by ranking these deficiencies based on frequency and magnitude of LOS exceedences; and

- develop and optimize proposed improvement alternatives.

Performance measures that quantify the magnitude of stormwater flooding problems generally have two components: the severity (i.e. how much does it flood?) and the frequency (i.e. how often does it flood?).

\subsubsection{Quantification of Flooding Severity}

In closed-conduit systems, particularly sanitary sewer (wastewater collection) systems, the severity of flooding is often quantified in terms of overflow volume and LOS objectives are often intended to eliminate or greatly reduce the magnitude of overflows. As a result, there is little need to quantify severity beyond an estimate of the volume that overflows the system. With stormwater systems, it is neither feasible nor cost-effective to completely contain within a natural stream or closed conduit, the stormwater runoff from all possible rainfall events. It is often necessary that some out-of-bank flooding or street flooding will occur under certain storm conditions and at certain locations along the stormwater system. In these cases, the volume of overflow does not sufficiently describe or quantify the flooding severity.

The quantity of stormwater that overflows the collection system can be measured in vertical, horizontal, and time dimensions, including:

- Depth. The depth of flooding is often measured in relation to structures (e.g. roads, buildings, parking lots, railways) or properties within, and adjacent to, the stormwater system. Along roadways, this can include the depth over the road crown, inside/ outside travel lanes, manhole rim, gutter, or inlets. In buildings, flooding can be measured as the depth above the finished floor or basement elevations of occupied dwelling units or businesses. In open channel systems, flooding can include the depth above the defined bank elevations.

- Areal extent. Depending on where the flooding problem is located, the areal extent of flooding can be used to quantify the severity of flooding. Examples include:

- Total area of inundation. This can include the area of outof-bank flooding in open channel systems and the area of surface flooding in closed conduit systems. 
- Number of structures flooded. This can include a count of roads that are inundated or deemed impassable and a count of residential and non-residential buildings that are inundated. Similarly, the number of structures that are threatened by flooding can also be determined based on the proximity of the inundated area to structures (e.g. within 20 feet $(6 \mathrm{~m})$ of building foundations).

- Length of inundated roads. Another useful indicator of flooding severity is the total length of roadway flooding. The number of lanes that various transportation routes (local roads, arterial routes, and interstate highways) are inundated and/or impassible can also be categorized. Similarly, the length of surcharged storm sewers or the length of outof-bank flooding in open channel systems can be used to quantify flooding.

- Duration of flooding. The duration of inundation is another useful indicator of flooding severity. For roadways, this can include the time that the street surface is inundated and/or deemed impassable. For buildings, the duration can include the time that critical elevations, such as the basement and first floor elevations are exceeded.

Other flow rate and velocity indicators can be used to measure flooding severity (e.g. duration that flow velocity exceeds a damaging or erosive value), but discussion in this chapter is limited to the depth, area and duration of inundation.

Figure 4.3 shows an example of various LOS classifications that can be used to categorize the depth of flooding allowed within and adjacent to a typical urban street right-of-way for a given design storm event. The classes are often assigned a letter grade and range from maximum roadway and building flood protection (Class A) to minimum building flood protection (Class D). When systems fail to meet the Class D criterion of no building flooding, they can be assigned to an additional class (Class E) that represents no flooding protection to either roadway or buildings if necessary.

Level of service classes for street and building flooding protection are described as follows:

- Service Class A provides the highest level of flood protection for roads and buildings where all flows are contained with the underground collection system. The street surface remains dry during and after the storm, all traffic lanes are open, and the 


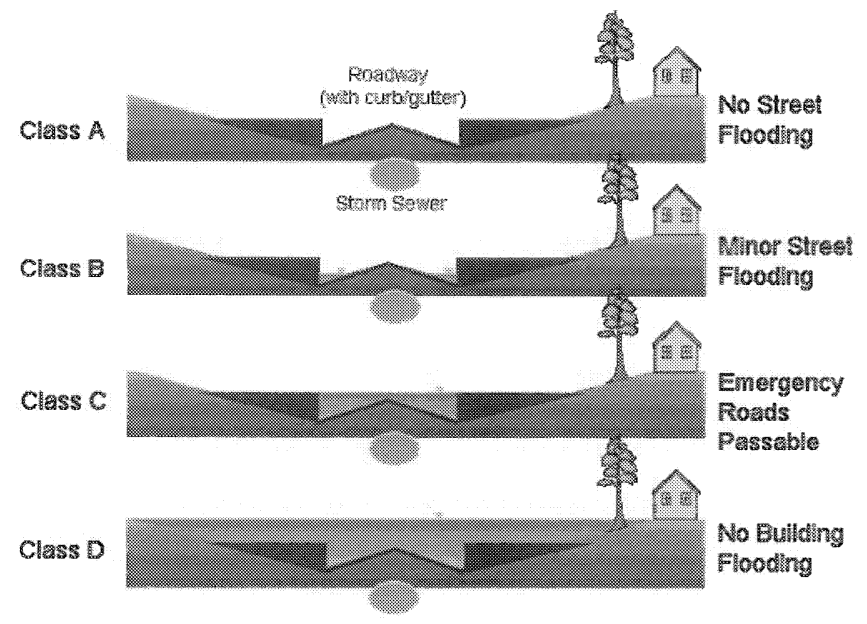

Figure 4.3 Example level of service classes for street and building flooding protection.

maximum hydraulic grade line is generally at or below the inlet throat elevation.

- Service Class B is the next level of protection and allows minimal street flooding, which is often limited to the outer travel lanes. The road crown remains dry to allow safe passage of vehicular traffic and there is no flooding of buildings. Level of service criteria might specify a minimum width of dry roadway surface (e.g. $12 \mathrm{ft}(3.7 \mathrm{~m})$ for normal traffic flow on local roads and $24 \mathrm{ft}$ $(7.3 \mathrm{~m})$ on collector, arterial and highway routes to allow travel in both directions).

- Service Class $C$ is a lower level of flood protection that allows the entire roadway surface to be inundated. Although the road crown is flooded, it is still deemed passable and does not prevent emergency ingress or egress (e.g. hurricane evacuation). There is no flooding of buildings.

- Service Class $D$ is the minimum level of flood protection for buildings. Roads are generally not passable, and property is threatened but buildings are not flooded at any time during and after the storm.

More elaborate classifications can be developed that assign multiple letter grades for severity levels for various structure types (i.e., individual service classes for streets, buildings, yards, railways). 


\subsubsection{Quantification of Flooding Frequency}

Rather than quantifying the frequency or return period of a given flooding event, it is common practice to specify the frequency of the rainfall event that causes the flooding. Rainfall events used can include design storm events or historical storms with an assigned frequency. Design storm events are synthetic rain sequences derived from long-term rainfall statistics for selected rain monitoring stations and vary widely by location. They are described by their duration in hours or days and by the return period of the rainfall amount over that duration. For example, a $24-\mathrm{h}, 25-\mathrm{y}$ storm event is one that is 24 hours in duration and has a $4 \%(1 / 25)$ chance of occurring during any given year.

Levels of service for flood control are generally defined by the maximum design storm event that can be controlled by the stormwater system. For example, a given street may be assigned a Class B LOS, where the maximum allowable depth of street flooding along the gutter is 3 inches $(75 \mathrm{~mm})$. Model results at a given location along the street indicate no flooding for the $2-y / 24-\mathrm{h}$ storm, 2 inches $(50 \mathrm{~mm})$ of flooding for the $5-\mathrm{y} / 24-\mathrm{h}$ storm, and 8 inches (200 $\mathrm{mm}$ ) of flooding for the $10-\mathrm{y} / 24-\mathrm{h}$ storm. Based on these results, the LOS criteria are met for the 2-y and 5-y storms, but the system fails to meet the criteria for the 10-y storm. As a result, the stormwater system is said to provide a 5-y Class B LOS at that location.

\subsubsection{Example Level of Service Criteria}

Defining stormwater level of service criteria is a process that requires public input and acceptance. As mentioned earlier, the diversity in public perception and attitudes toward stormwater flooding has resulted in a wide variety of adopted stormwater LOS criteria. Even after a local government has adopted LOS criteria, the high cost of maintaining stormwater infrastructure at the desired service levels might lead to periodic refinement of these criteria so that it is commensurate with available funding.

In the U.S., there are a wide variety of state and federal regulatory mandates and legal requirements for controlling street flooding to specific levels. Local governments often include street flooding LOS criteria within their engineering design standards, but these typically apply only to secondary stormwater systems (e.g., inlet design criteria based on the allowable spread of water across the pavement). Building flooding LOS criteria however, are more consistent throughout the nation and are often based upon flood insurance requirements in the regulated floodplain. 
Table 4.1 shows the stormwater LOS criteria that are currently used by the City of St Petersburg, Florida (CDM, 2000). These criteria are grouped by traffic route categories and by design storm events. Maximum flooding depths are related to the depth above the inlet throat, road crown, top of bank, and/or building finished floor elevations of occupied dwelling units. For example, street flooding along four-lane collector roadways that are designated emergency evacuation routes cannot exceed 3 inches $(0.25 \mathrm{ft}, 75 \mathrm{~mm})$ above the inlet throat elevation for the $10-\mathrm{y} / 1 \mathrm{-h}$ storm event, 3 inches below the road crown for the 25-y/24-h storm, and no building flooding for the 100-y/24-h storm.

Drainage goals and objectives in various coastal Florida communities aimed for passable roads during design storm events that ranged from 2-year to 25-y return periods (City of Naples, 1997; Collier County, 1997; CDM, 1999, $2000,2001)$. The interpretation of "passable" differed between local governments and the various LOS criteria called for maximum depths of street flooding

Table 4.1 Example level of service criteria (St. Petersburg, Florida).

\begin{tabular}{|c|c|c|c|c|}
\hline $\begin{array}{l}\text { Level of } \\
\text { Service } \\
\text { Category }\end{array}$ & & \multicolumn{3}{|c|}{ Maximum Allowable Flooding Depths } \\
\hline Category & Description & $\begin{array}{l}10-\mathrm{y} / 1-\mathrm{h} \\
\text { event }\end{array}$ & $\begin{array}{l}25-y / 24-h \\
\text { event }\end{array}$ & $\begin{array}{c}100-y / 24-h \\
\text { event }\end{array}$ \\
\hline $\mathrm{A} 2$ & two-lane arterial & $0 \mathrm{ft}$ above inlet & $\begin{array}{r}\text { no building } \\
\text { flooding }\end{array}$ & $\begin{array}{r}\text { no building } \\
\text { flooding }\end{array}$ \\
\hline A4 & $\begin{array}{l}\text { four-lane arterial } \\
\text { four-lane }\end{array}$ & $0.25 \mathrm{ft}$ above inlet & $\begin{array}{r}\text { no building } \\
\text { flooding }\end{array}$ & $\begin{array}{r}\text { no building } \\
\text { flooding }\end{array}$ \\
\hline $\mathrm{A} 4 / \mathrm{E}$ & $\begin{array}{l}\text { arterial/ } \\
\text { emergency }\end{array}$ & $0.25 \mathrm{ft}$ above inlet & $\begin{array}{r}0.25 \mathrm{ft} \text { below } \\
\text { crown }\end{array}$ & $\begin{array}{r}\text { no building } \\
\text { flooding }\end{array}$ \\
\hline $\mathrm{C} 2$ & $\begin{array}{l}\text { two-lane } \\
\text { collector }\end{array}$ & $0 \mathrm{ft}$ above inlet & $\begin{array}{r}\text { no building } \\
\text { flooding }\end{array}$ & $\begin{array}{r}\text { no building } \\
\text { flooding }\end{array}$ \\
\hline $\mathrm{C} 2 / \mathrm{E}$ & $\begin{array}{l}\text { two-lane } \\
\text { collector/ } \\
\text { emergency }\end{array}$ & $0 \mathrm{ft}$ above inlet & $\begin{array}{r}0.25 \mathrm{ft} \text { below } \\
\text { crown }\end{array}$ & $\begin{array}{r}\text { no building } \\
\text { flooding }\end{array}$ \\
\hline $\mathrm{C} 4$ & $\begin{array}{l}\text { four-lane } \\
\text { collector }\end{array}$ & $0.25 \mathrm{ft}$ above inlet & $\begin{array}{r}\text { no building } \\
\text { flooding }\end{array}$ & $\begin{array}{r}\text { no building } \\
\text { flooding }\end{array}$ \\
\hline $\mathrm{C} 4 / \mathrm{E}$ & $\begin{array}{l}\text { four-lane } \\
\text { collector/ } \\
\text { emergency }\end{array}$ & $0.25 \mathrm{ft}$ above inlet & $\begin{array}{r}0.25 \mathrm{ft} \text { below } \\
\text { crown }\end{array}$ & $\begin{array}{r}\text { no building } \\
\text { flooding }\end{array}$ \\
\hline $\mathrm{O}$ & open channel & $\begin{array}{r}0 \mathrm{ft} \text { above top of } \\
\text { bank }\end{array}$ & $\begin{array}{r}\text { no building } \\
\text { flooding }\end{array}$ & $\begin{array}{r}\text { no building } \\
\text { flooding }\end{array}$ \\
\hline $\mathrm{R}$ & residential route & $0.75 \mathrm{ft}$ above inlet & $\begin{array}{r}\text { no building } \\
\text { flooding }\end{array}$ & $\begin{array}{r}\text { no building } \\
\text { flooding }\end{array}$ \\
\hline
\end{tabular}


in the range of 0 to 12 inches ( 0 to $300 \mathrm{~mm}$ ). Often, passable roads were defined in terms of eliminating nuisance flooding, which can be subjective and is often dictated by user expectations as mentioned earlier. A more objective definition of impassable roads can be based on the depth to drive train or ground clearance of a typical car, which is of the order of 8 inches $(200 \mathrm{~mm})$.

Another common feature in these communities was that different roads were assigned different service levels depending upon traffic volume, alternative points of ingress/egress, or other factors. For example, during a 10-y storm, an interstate highway may be assigned a Class A LOS, while a residential side street that can be accessed from two directions may be assigned Class D LOS. In addition, a different service level may be assigned to the same road for different design storms. For example, along interstate highways it may be desired to achieve Class A LOS during a 10-y event, Class B during a 25-y event, and Class $\mathrm{C}$ during a 50 -y event.

There were variations in land use as well, such that roads in key institutional zones (e.g. hospitals, schools, fire stations) were assigned to a higher LOS class than roads in residential areas, for example. There was much more uniformity in LOS criteria for building flooding, and the majority of communities called for no building flooding for the 100-y design storm event.

\subsection{System Performance Assessment}

Section 4.2 described issues in the development of LOS standards and gave typical criteria that have been adopted by various local governments. This section describes how these LOS criteria can be used in conjunction with computer model results to assess the performance of stormwater systems.

It is unlikely that the entire stormwater system meets the local government's adopted LOS criteria. There are many reasons why existing systems do not provide a uniform LOS, including:

- Older systems designed to a lower level of service.

- Improper maintenance and operation, and general aging and deterioration of the system resulting in structural deficiencies.

- Changes in land use and new development upstream have increased stormwater flows beyond the original design capacity of the system.

- A piecemeal approach to rehabilitation where repairs or improvement projects were implemented without considering their effect on the overall system. For example, an improvement project may 
have solved local flooding problems but worsened flooding problems upstream or downstream.

- Additional factors such as different owners and system managers, erratic funding and other financial constraints, implementation of new technologies, and the adoption of new LOS criteria engineering design standards and/or new design storm events (based on new rainfall statistics).

An LOS evaluation helps to establish model credibility if the model corroborates observed behavior by identifying system deficiencies where there are known flooding problem areas. Furthermore, this evaluation can identify new problem areas under a variety of design storm events and/or different land use scenarios, and the LOS criteria can be used to provide an objective basis for prioritizing problem areas. Finally, the criteria used in the LOS analysis may be revised and adapted to help guide the development and optimization of proposed improvement alternatives to address flooding in these problem areas.

In order to quantify structural flooding, the stormwater model must include a representation of surface overflows. In open channel systems this can include road overflows at bridges or culvert crossings as well as additional floodplain storage areas. In closed conduit systems, surface overflows may be conveyed down streets, alleys, or other surface routes to the next available stormwater inlet or open channel. Overflows may also be impounded in surface depressions such as parking lots, back yards or other areas. If stormwater overflows the collection system and spills into these surface channels and depressions, then these features must be represented appropriately in the computer model.

It is also important to have a good inventory of surveyed structure elevations. At a minimum, a critical or threshold elevation should be recorded for each model junction (e.g. representing the lowest road crown elevation or building elevation in the vicinity). Ideally, all low-lying structures in the vicinity of each model junction should be compiled, so that the number, depth and duration of flooding can be quantified. To quantify the area and length of inundation, floodplain-mapping tools will likely be required (Gregory et al., 2001).

Modeling is a valuable tool for corroborating and complementing field observations. Furthermore, the proper application of modeling tools and techniques can provide improved understanding of important cause-effect relationships that goes beyond the simple observation that a problem exists. Calibration, validation, and verification provide a vital reality check by comparing model results to observed behavior under a variety of conditions. It is only 
with a thorough understanding of the scope and range of flooding problems that effective improvement measures can be developed. The exercise of calibrating, validating, and verifying a model will maximize the use of available data and, combined with a comprehension of observed flooding problems, lead to a better understanding of these problems in a system-wide context, thereby improving confidence and reliability in model results.

Calibration refers to the adjustment of model parameters so that computed results match a set of relatively precise observations for a series of storm events. In this chapter, validation refers to the process of comparing results from the calibrated model (and adjusting model parameters as necessary) to different storm events, often with less precise measurements or other information from historical storm events. Validation data may include independent calibration events, results from other studies and reports, measured high water marks or debris lines, pump station records, photographs taken during the storm, flooding complaint records and insurance claims, newspaper and scientific journal articles, for example. Calibration and validation issues and methodologies are described in detail elsewhere (Cunningham et al., 1998; Gregory et al., 2000). This chapter uses the term verification to refer to the process of comparing results from the validated model (and adjusting model parameters as necessary) to anecdotal information and/or public memory of qualitative characteristics of flooding for the larger, less frequent design storm events.

Calibration data are often based on measurements recorded during the smaller storm events where runoff is contained within the collection system. During the larger storm events where flooding is widespread, the conveyance and storage characteristics of stormwater flows are very different from those observed at low flow conditions. If the calibration and validation were solely based on small storm events, results would be biased towards low flow hydraulic conditions and may not accurately reflect the more extreme flood conditions. Model verification goes beyond calibration by comparing model results to observed characteristics of the stormwater system under extreme rainfall and high flow conditions.

A typical verification procedure will involve determining which parts of the stormwater system pass or fail to achieve the desired LOS criteria for street and building flooding for a range of design storm events. Results can then be verified by interviewing municipal staff or residents who have lived in the area for a long time. The intent of this review is to make sure that the LOS evaluation confirms known problem areas, and that the model does not identify problems where it is known that none exist. 
Model verification is not as objective or precise as calibration or validation, but can lead to a credible model for high-flow conditions. Furthermore, both model calibration and validation are used to compare computed and observed behavior at selected points within the watershed. Verification, using the LOS approach, can be used to evaluate flooding throughout the entire system.

\subsection{Level of Service Evaluations: Case Studies}

Two case studies are presented in this section that illustrate concepts presented earlier. In each case, the LOS evaluation served two concurrent purposes: a performance assessment of the existing system under existing land use conditions, and a verification of the calibrated and validated model.

\subsubsection{Bay County, Florida}

This work was conducted as part of the East Hiland Park Stormwater Drainage Plan (CDM, 1999). The East Hiland Park watershed is primarily residential and has a tributary area of $1.5 \mathrm{mi}^{2}\left(3.9 \mathrm{~km}^{2}\right)$. It is located in south central Bay County, approximately 5 miles $(8 \mathrm{~km})$ northeast of Panama City. The stormwater system consists of roadside swales and ditches, driveway and road crossing culverts that discharge into a tributary of Mill Bayou, which ultimately discharges south into the Gulf of Mexico. The U.S. Environmental Protection Agency (EPA) StormWater Management Model (SWMM) was used to simulate the hydrology and hydraulics within the East Hiland Park watershed. For this study, the watershed was subdivided into 19 hydrologic units (i.e., subbasins), ranging in size from 2 to 459 acres ( 0.8 to $186 \mathrm{ha}$ ) with an average area of 50 acres $(20 \mathrm{ha})$. The stormwater system included 31 closed conduits with a length of $0.3 \mathrm{mi}(0.5 \mathrm{~km})$ and 19 open-channel reaches with a length of $1.9 \mathrm{mi}(3.1 \mathrm{~km})$. Additional street channels, road overtopping weirs and storage areas were used to represent the surface overflow system.

The model was calibrated to ten surveyed high water mark locations throughout the watershed for the September 2, 1998 storm event. After the model was calibrated, a preliminary LOS evaluation was performed to indicate occurrences of street and building flooding for a range of storm events. County staff reviewed these results and the calibrated model was refined and updated Although street flooding occurrences were relatively minor, chronic building and property flooding have been reported in the area, because many of the homes were built significantly lower than the adjacent road centerline elevation. 
A summary of building flooding results for the existing system under existing land use conditions is presented in Table 4.2. The table shows locations throughout the watershed where building flooding is predicted for the 100-y/ 24-h design storm event. The model junction name, its location, and a summary of the predicted building flooding depths for each storm event are given. The depth of building flooding was determined by comparing the peak computed water surface elevation with the lowest surveyed building finished floor elevation in the vicinity of the junction. The most severe flooding occurs at junction HP420, where $0.1 \mathrm{ft}(30 \mathrm{~mm})$ of flooding is indicated for the 5 -y event and $1.3 \mathrm{ft}(400 \mathrm{~mm})$ of flooding for the 100-y event. No flooding is indicated for the 2-y event, consequently a 2-y building flooding LOS is provided by the stormwater system at this location.

By assigning a single building floor elevation to each junction (i.e. the critical building with the lowest elevation), Table 4.2 only indicates the maximum depth of building flooding and does not indicate how many buildings are impacted. To quantify the areal extent of flooding, inundation maps were

Table 4.2 East Hiland Park, building flooding LOS evaluation. Maximum depths of building flooding.

\begin{tabular}{|c|c|c|c|c|c|c|c|}
\hline \multirow{2}{*}{$\begin{array}{l}\text { Junction } \\
\text { Name } \\
\end{array}$} & \multirow[t]{2}{*}{ Location } & \multicolumn{6}{|c|}{ Depth of Building Flooding ( $\mathrm{ft}$ ) } \\
\hline & & $\begin{array}{l}2-y / \\
24-h \\
\text { Event }\end{array}$ & $\begin{array}{l}5-\mathrm{y} / \\
24-\mathrm{h} \\
\text { Event }\end{array}$ & $\begin{array}{l}10-y / \\
24-h \\
\text { Event }\end{array}$ & $\begin{array}{l}25-\mathrm{y} / \\
24-\mathrm{h} \\
\text { Event }\end{array}$ & $\begin{array}{l}100-y / \\
24-h \\
\text { Event }\end{array}$ & $\begin{array}{l}\text { Level of } \\
\text { Service } \\
\text { Provided }\end{array}$ \\
\hline HP160 & $\begin{array}{l}\text { Orlando Rd } \\
\text { (north side) }\end{array}$ & & & & & 0.5 & $25-y$ \\
\hline HP170 & $\begin{array}{l}\text { Orlando Rd } \\
\text { (north side) }\end{array}$ & & & & 0.1 & 0.7 & $10-y$ \\
\hline HP400 & $\begin{array}{l}\text { Orlando Rd } \\
\text { (north side) }\end{array}$ & & & & & 0.2 & $25-y$ \\
\hline HP410 & $\begin{array}{l}\text { Orlando Rd } \\
\text { (north side) }\end{array}$ & & & 0.5 & 0.6 & 0.9 & $5-y$ \\
\hline HP420 & $\begin{array}{l}\text { Orlando Rd } \\
\text { (north side) }\end{array}$ & & 0.1 & 0.7 & 0.9 & 1.3 & $2-y$ \\
\hline HP430 & $\begin{array}{l}\text { Orlando Rd } \\
\text { (north side) }\end{array}$ & & & 0.6 & 0.8 & 1.3 & $5-y$ \\
\hline HP510 & $\begin{array}{l}\text { Orlando Rd/ } \\
\text { Glenview Av }\end{array}$ & & & & & 0.1 & $25-\mathrm{y}$ \\
\hline
\end{tabular}


created from digital topographic data. The inundation boundaries for each design storm event were then plotted on the digital aerial photographs and the number of flooded structures was counted.

Table 4.3 shows the count of buildings whose footprint (either partially or fully) overlapped the predicted inundation boundary for each design storm event. The structures were distinguished by building type: the house (i.e. the occupied dwelling unit) and the garage. House flooding was given higher priority over garage flooding in the development of proposed improvement alternatives. As indicated in both Tables 4.2 and 4.3, no building flooding was indicated for the 2-y event. For the 5-y event, building flooding was predicted for 6 houses and 2 garages, while 75 houses and 20 garages were predicted to flood for the 100-y event.

By considering results of the LOS evaluation, the severity and frequency of building flooding in the East Hiland Park watershed was sufficiently quantified. This in turn provided the basis of comparison in the development of improvement alternatives.

Table 4.3 East Hiland Park, building flooding LOS evaluation. Number of building flooding occurrences.

\begin{tabular}{cccccr}
\hline Building & \multicolumn{5}{c}{ Number of Building Flooding Occurrences } \\
\hline Type & 2-y/24-h & $5-\mathrm{y} / 24-\mathrm{h}$ & $10-\mathrm{y} / 24-\mathrm{h}$ & $25-\mathrm{y} / 24-\mathrm{h}$ & $100-\mathrm{y}$ \\
& Event & Event & Event & Event & Evf \\
\hline Residential House & 0 & 6 & 14 & 31 & $7:$ \\
Residential Garage & 0 & 2 & 12 & 15 & 21 \\
Total & 0 & 8 & 26 & 46 & 9 \\
\hline
\end{tabular}

\subsubsection{Clearwater, Florida}

This analysis was conducted as part of the Myrtle Avenue Stormwater Improvement Project, Phase 1 (CDM, 2001). The Downtown watershed is $0.8 \mathrm{mi}^{2}\left(2.1 \mathrm{~km}^{2}\right)$ in area and drains the central portion of Clearwater watershed, which is primarily commercial land use. The storm sewer system features a network of pipes with four major outfalls that discharge to the west into Clearwater Harbor in the Gulf of Mexico. The Downtown watershed was modeled using EPA SWMM and was subdivided into 83 hydrologic units, ranging in size from less than 1 acre to 21 acres ( 0.4 to $8.5 \mathrm{ha})$ with an average area of 6.4 acres $(2.6 \mathrm{ha}$ ). The stormwater system included 206 closed conduits 
with a total length of 7.5 miles $(12.1 \mathrm{~km})$. There were no open-channel reaches in the collection system. Additional street channels, road overtopping weirs and storage areas were used to represent the surface overflow system.

The model was calibrated to measured rainfall and stages for a 35-d continuous period from June 11 to July 16, 2000. There were a total of 14 discrete rainfall events over this period. The largest event occurred on July 15 and featured 5.9 inches $(150 \mathrm{~mm})$ of rain over $9.5 \mathrm{~h}$, which was close to a $25-\mathrm{y}$ return period. The model was further validated using surveyed high water marks and flooding complaint records at 10 locations throughout the watershed for the July 15 event. As with the previous case study, the model was further verified by performing a LOS evaluation for street and building flooding. Based on review comments by City staff, the validated model was refined and updated until all known flooding problem areas were indicated by model results.

The purpose of the study was to evaluate and develop improvements to alleviate chronic street and building flooding occurrences along Myrtle Avenue. The City's desired LOS criteria for Myrtle Avenue are a maximum of 3 inches $(0.25 \mathrm{ft}, 75 \mathrm{~mm})$ over the road crown and no building flooding.

Table 4.4 shows computed street flooding along Myrtle Avenue, along with the resulting LOS provided (i.e. the maximum design storm event for which LOS criteria are achieved). For example, computed street flooding at junction NMyrtle8 meets the LOS criteria (i.e. less than 3 inches) for the 5-y event, but exceeds it for the 10-y event and so provides a 5-y LOS at this location. The table shows the most severe occurrences of computed street flooding along Myrtle Avenue within the project study area. Table 4.5 shows similar LOS evaluation results for building flooding along Myrtle Avenue.

Inundation statistics (e.g. length of streets inundated or number of buildings flooded) were not computed due to the unavailability of digital topographic contours. However, as in the previous case study, the quantification of flooding severity and frequency was sufficient to quantify the extent of street and building flooding, and provided a sound basis for developing proposed improvement alternatives.

\subsection{Conclusions}

A level of service evaluation is a condition assessment of a stormwater system to determine its level of performance with respect to site-specific numeric LOS criteria. These LOS criteria can be used as benchmarks to gage the performance of existing assets and facilitate proper management decisions concerning the 
Table 4.4 Myrtle Avenue, street flooding LOS evaluation. Maximum depths of street flooding.

\begin{tabular}{|c|c|c|c|c|c|c|c|}
\hline Junction & Description & $\begin{array}{l}\text { Predicted Building } \\
\text { Flooding Depth } \\
\text { (ft) }\end{array}$ & & & & & Level of \\
\hline Name & & $2-\mathrm{y} / 24-\mathrm{h}$ & $\begin{array}{l}5-\mathrm{y} / \\
24-\mathrm{h}\end{array}$ & $\begin{array}{l}10-\mathrm{y} / \\
24-\mathrm{h}\end{array}$ & $\begin{array}{l}25-\mathrm{y} / \\
24-\mathrm{h}\end{array}$ & $\begin{array}{l}100-\mathrm{y} / \\
24-\mathrm{h}\end{array}$ & Service \\
\hline & & Event & Event & Event & Event & Event & Provided \\
\hline NMyrtle 7 & $\begin{array}{l}\text { N. Myrtle Ave. } \\
\text { at Jones St. }\end{array}$ & & & 0.0 & 0.3 & 0.6 & $5-\mathrm{y}$ \\
\hline NMyrtle 1 & $\begin{array}{l}\text { N. Myrtle Ave. } \\
\text { at Laura St. }\end{array}$ & & & & & 0.0 & $25-\mathrm{y}$ \\
\hline SMyrtle22 & $\begin{array}{l}\text { S. Myrtle Ave. } \\
\text { at Cleveland St. }\end{array}$ & & 0.7 & 0.9 & 1.0 & 1.1 & $2-y$ \\
\hline SMyrtle21 & $\begin{array}{l}\text { S. Myrtle Ave. } \\
\text { at Park St. }\end{array}$ & & 0.3 & 0.5 & 0.7 & 1.0 & $2-y$ \\
\hline SMyrtle20 & $\begin{array}{l}\text { S. Myrtle Ave. } \\
\text { n. of Pierce St. }\end{array}$ & & & & & 0.1 & $25-\mathrm{y}$ \\
\hline SMyrtle 19 & $\begin{array}{l}\text { S. Myrtle Ave. } \\
\text { at Pierce St. }\end{array}$ & & & 0.1 & 0.3 & 0.5 & $5-y$ \\
\hline SMyrtle 18 & $\begin{array}{l}\text { S. Myrtle Ave. } \\
\text { at Pierce St. }\end{array}$ & & & & 0.2 & 0.4 & $10-y$ \\
\hline SMyrtle 17 & $\begin{array}{l}\text { S. Myrtle Ave. } \\
\text { at Franklin St. }\end{array}$ & & & 0.1 & 0.4 & 0.8 & $5-\mathrm{y}$ \\
\hline SMyrtle 16 & $\begin{array}{l}\text { S. Myrtle Ave. } \\
\text { at Franklin St. }\end{array}$ & & & & & 0.1 & $25-y$ \\
\hline SMyrtle 15 & $\begin{array}{l}\text { S. Myrtle Ave. } \\
\text { at Court St. }\end{array}$ & & & 0.2 & 0.4 & 0.7 & $5-\mathrm{y}$ \\
\hline SMyrtle 14 & $\begin{array}{l}\text { S. Myrtle Ave. } \\
\text { n. of Chestnut. }\end{array}$ & & & 0.2 & 0.5 & 0.7 & $5-y$ \\
\hline SMyrtle13 & $\begin{array}{l}\text { S. Myrtle Ave. } \\
\text { at Chestnut St. }\end{array}$ & & & 0.3 & 0.7 & 0.9 & $5-y$ \\
\hline SMyrtle 10 & $\begin{array}{l}\text { S. Myrtle Ave. } \\
\text { at Pine St. }\end{array}$ & & 0.1 & 0.6 & 1.1 & 1.7 & $2-y$ \\
\hline SMyrtle9 & $\begin{array}{l}\text { S. Myrtle Ave. } \\
\text { at Pine St. }\end{array}$ & & & & 0.2 & 0.8 & $10-y$ \\
\hline SMyrtle3 & $\begin{array}{l}\text { S. Myrtle Ave. } \\
\text { at Jeffords St. }\end{array}$ & 0.1 & 0.3 & 0.4 & 0.4 & 0.4 & $<2-y$ \\
\hline
\end{tabular}

administration, operation, maintenance, and capitalization of stormwater systems and facilities. Level of service standards and criteria adopted by local governments should be flexible enough to allow for the variation in service expectations of customers served by the system in order for LOS evaluations to be consistent with societal goals. 
Table 4.5 Myrtle Avenue, building flooding LOS evaluation. Maximum depths of building flooding.

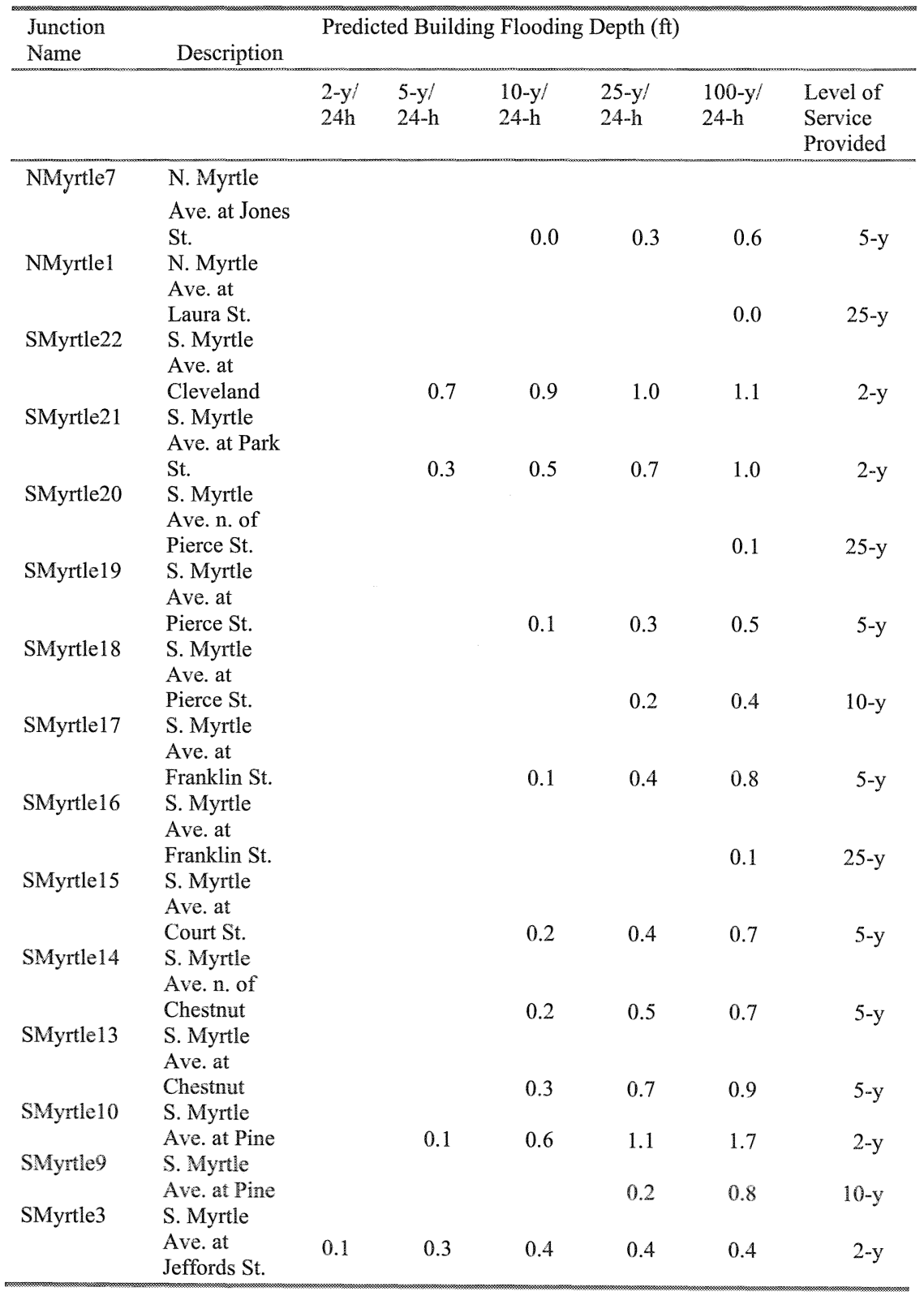


Flooding severity and frequency are key measures of the magnitude of stormwater flooding problems and these are commonly embodied in adopted LOS criteria. An LOS evaluation applies LOS criteria to computer model results for a variety of storm events and determines, on a reach-by-reach or junctionby-junction basis, whether the system meets or fails to achieve these criteria.

An LOS evaluation can be used as a predictive tool to evaluate the system performance in a comprehensive, system-wide context. The performance can be assessed over a range of storm events, land use scenarios, or alternate LOS criteria. Two case studies were presented in this chapter that highlight some of the practical applications of LOS evaluations, including corroboration of observed system behavior, verification of model results, and an identification of existing system deficiencies and problem areas. Additional applications can include identifying future problem areas and prioritizing existing and future problem areas. The LOS evaluation may then serve as a basis for developing and optimizing design proposed improvement alternatives to solve existing and future problems.

\section{References}

CDM (1999), Bay County (Florida) East Hiland Park Stormwater Drainage Plan, Final Report.

CDM (2000), City of St. Petersburg (Florida) Euclid-St. Paul's Neighborhood Storm Drainage Improvements, Phase 1, Final Report.

CDM (2001), City of Clearwater (Florida) Myrtle Avenue Stormwater Improvement Project, Phase 1, Final Report.

City of Naples, Florida (1997), Draft Comprehensive Plan.

Collier County, Florida (1997), Growth Management Plan, Public Facilities Element,

Drainage Sub-element, Ordinance 97-61, Adopted October 28, 1997.

Cunningham, B., Schmidt, M., Mack, B., and Gregory, M. (1998); Issues and

Approaches in the Calibration and Verification of Water Quantity Models; conference proceedings of the 1998 Florida Water Resources Conference, Fort Lauderdale, Florida.

Gregory, M., Walker, B., Yi, S., Cunningham, B., and Kjelds, J. (2001); Case Studies in Automated Floodplain Mapping; conference proceedings of the 2001 Urban Drainage Modeling Symposium, Orlando, Florida.

Gregory, M., Mack, B., Schmidt, M., and Cunningham, B. (2000); Calibration and Validation: Keys to Building a Reliable Stormwater Model; conference proceedings of the 2000 Florida Water Resources Conference, Tampa, Florida.

Huber, W. C. and Dickinson, R. E. (1988). SWMM Version 4 User's Manual. US

Environmental Protection Agency. 
National Research Council (1994), Toward Infrastructure Improvement: An Agenda for Research, James P. Gould and Andrew C. Lerner (Editors).

Roesner, L. and Matthews, R. (1990), Stormwater Management for the 1990s. American City and County, February issue. 
